\title{
OPTIMALISASI PERAN ZAKAT DALAM MEMBERDAYAKAN PEREKONOMIAN UMAT
}

\author{
M Nur Rianto Al Arif \\ Fakultas Syariah dan Hukum UIN Syarif Hidayatullah Jakarta \\ Jl. Ir. H. Juanda No. 95 Ciputat, Tangerang Selatan, Banten \\ email: hakam_alarif@yahoo.com
}

\begin{abstract}
The government poverty alleviation program could not give a significant change to reduce poverty. It needed a support from other sub-system, such as zakah. Zakah, as one of the Islamic fiscal instruments has played a significant role in Islamic economic. The potential of zakah would cover several aspects like poverty alleviation program through social welfare system. Zakah could obtain a social welfare system such as workplace accident insurance, old age pension, pension insurance, and death insurace. In addition, other problems such as housing for the poor, capital investment and education could be cared through zakah if zakah was managed and developed in a maximal way.

Program pengentasan kemiskinan yang dijalankan oleh pemerintah masih belum memberikan dampak yang signifikan terhadap penurunan tingkat kemiskinan. Ia membutuhkan dukungan dari sub sistem lain termasuk zakat. Zakat merupakan salah satu instrumen fiskal Islam yang telah memberikan peranan cukup signifikan dalam sistem ekonomi Islam. Potensi zakat akan mampu mencakup berbagai macam aspek termasuk untuk program pengentasan kemiskinan dalam bentuk sistem jaminan sosial. Zakat dapat dipergunakan dalam berbagai bentuk sistem jaminan sosial, seperti asuransi tenaga kerja, asuransi pensiun dan asuransi jiwa. Serta untuk mengatasi berbagai macam masalah seperti perumahan, akses permodalan dan pendidikan bagi si miskin yang dapat dilakukan melalui maksimalisasi pengelolaan dan pendayagunaan zakat.
\end{abstract}

Key words: poverty, social welfare system, zakah, tax

Ulul Albab Volume 14, No.1 Tahun 2013 


\section{Pendahuluan}

Di setiap negara selalu menghadapi permasalahan sosial yaitu kemiskinan baik kemiskinan yang bersifat absolut maupun kemiskinan bersifat relatif. Kemiskinan absolut merupakan tingkat kemiskinan yang diukur berdasarkan suatu garis kemiskinan tertentu. Sementara kemiskinan relatif merupakan tingkat kemiskinan yang diukur secara relatif antar penduduk. Kompleksitas penyelesaian permasalahan kemiskinan disebabkan pendekatan yang dilakukan tidak hanya dari aspek ekonomi semata namun aspek sosial harus dipertimbangkan. Selain itu tidak terjadinya pemerataan hasil pembangunan juga merupakan faktor penyebab yang tidak dapat diabaikan.

Sharp mencoba melakukan identifikasi penyebab kemiskinan dari segi ekonomi (Kuncoro, 1997: 30). Pertama, kemiskinan secara mikro lahir karena adanya ketidaksamaan pola kepemilikan sumber daya. Kedua, kemiskinan muncul sebagai akibat perbedaan dalam kualitas sumber daya manusia. Ketiga, kemiskinan muncul sebagai akibat perbedaan akses dalam modal. Ketiga penyebab kemiskinan ini menurut Nurske akan bermuara pada suatu teori lingkaran setan kemiskinan (the vicious circle of poverty), dimana menurutnya "a poor country is poor because it is poor".

Dalam upaya untuk mengatasi kemiskinan, pemerintah telah mengeluarkan berbagai kebijakan agar permasalahan kemiskinan ini dapat terselesaikan, antara lain dengan kebijakan (1) Inpres Desa Tertinggal (IDT); (2) Jaring Pengaman Sosial (JPS) yang dikeluarkan pada saat krisis; (3) PNPM Mandiri; dan banyak program pengentasan kemiskinan dan pemberdayaan masyarakat lainnya. Namun seluruh program tersebut masih belum dapat menyelesaikan permasalahan ini. Seluruh program pengentasan kemiskinan yang telah dilaksanakan oleh pemerintah dengan tujuan untuk memberdayakan masyarakat terutama masyarakat miskin masih belum mampu memperlihatkan hasil yang signifikan di masyarakat.

Hal ini menandakan bahwa program pemberdayaan masyarakat masih membutuhkan dukungan dari sub sistem lain. Dukungan dari sub sistem selain pemerintah sangat dibutuhkan agar manfaat pemberdayaan masyarakat dapat semakin berdayaguna dalam meningkatkan kemaslahatan masyarakat. Salah satu sub sistem yang dapat mendukung program pemberdayaan masyarakat yang dilaksanakan oleh pemerintah adalah dengan mengoptimalkan sumbersumber keuangan Islam termasuk zakat.

Wacana yang telah berkembang pada saat ini adalah zakat produktif, dimana zakat diarahkan untuk bantuan yang bersifat produktif agar masyarakat 
yang tidak mampu pada akhirnya akan dapat menjadi mandiri tanpa bantuan orang lain. Namun penerapan zakat produktif bukan berarti sama sekali tidak memberikan bantuan yang sifatnya konsumtif. Bantuan konsumtif pun masih diperlukan, selama proses transisi pemberdayaan masyarakat tersebut. Sebab program pemberdayaan masyarakat menjadi mandiri akan membutuhkan waktu yang tidak sebentar.

Berdasarkan berbagai penjelasan di atas, terlihat bahwa berbagai program kemiskinan yang dijalankan oleh pemerintah masih belum mampu mengentaskan kemiskinan, sehingga memerlukan peran serta aktif sub sistem perekonomian lain. Salah satu sub sistem yang akan dibahas dalam tulisan ini adalah untuk melihat seberapa jauhkan zakat mampu memberdayakan perekonomian umat. Teknik yang dipergunakan dalam penulisan artikel ini ialah menggunakan grounded theory method, dimana berupaya menjelaskan kajian zakat dari aspek teoritis kemudian mengaitkannya dengan aplikasi yang terjadi di masyarakat.

\section{Definisi Zakat}

Zakat merupakan salah satu kewajiban yang disyari'atkan Allah kepada umat Islam, sebagai salah satu perbuatan ibadah setara dengan shalat, puasa dan ibadah haji. Akan tetapi, zakat tergolong ibadah ma'liah, yakni ibadah melalui harta kekayaan dan bukan ibadah badaniah yang pelaksanaannya dengan fisik. Hal inilah yang membedakan zakat dengan ibadah ritual lainnya, seperti ibadah shalat, puasa maupun haji, dimana manfaatnya hanya terkena kepada individu tersebut semata, sedangkan zakat manfaatnya bukan untuk individu tersebut semata namun bermanfaat pula bagi orang lain. Allah mewajibkan zakat kepada individu yang mampu dengan tujuan untuk mengetahui seberapa besar cinta hamba kepada Penciptanya daripada dengan hartanya, sebab secara naluri alamiah manusia memiliki kecenderungan merasa sangat berat apabila harus berkorban dengan hartanya, sehingga dengan kewajiban zakat ini, akan mampu memperlihatkan sosok manusia beriman sejati apakah lebih sayang terhadap hartanya ataukah terhadap Penciptanya.

Ibadah zakat mempunyai dua aspek, yaitu aspek hubungan manusia dengan Allah SWT (hablum minallah) dan aspek hubungan manusia dengan sesama (hablum minannas). Aspek hubungan dengan Allah SWT adalah dengan membayar zakat berarti kita mematuhi dan mentaati apa yang telah diperintahkan-Nya, ini menandakan wujud kecintaan seorang hamba kepada Penciptanya. Seseorang dapat dikatakan beriman jika ia bersedia mematuhi 
segala hal yang diperintahkan oleh Penciptanya, termasuk dalam hal kewajiban menunaikan zakat. Selain itu dengan membayar zakat menandakan bahwa seorang hamba telah bersyukur kepada sang Pencipta atas semua rejeki, nikmat dan karunia yang telah diberikan kepadanya. Wujud syukur tidaklah cukup hanya dengan ucapan "alhamdulillah" semata, melainkan harus dibuktikan pula dengan perbuatan, dan dengan membayar zakat maka itu menjadi bukti bahwa kita telah bersyukur dengan melakukan suatu perbuatan dan tidak hanya dengan ucapan saja.

Ditinjau dari segi bahasa, kata zakat mempunyai beberapa arti yaitu al barakatu (keberkahan), al namaa (pertumbuhan dan perkembangan), ath thaharatu (kesucian) dan ash shalahu (keberesan). Makna keberkahan yang terdapat pada zakat berarti dengan membayar zakat, maka zakat tersebut akan memberikan berkah kepada harta yang dimiliki dan Insyaallah akan membantu meringankan kita di akhirat kelak, sebab salah satu harta yang tidak akan hilang meskipun sampai kita di alam barzah adalah amal jariyah selain doa anak yang saleh dan ilmu yang bermanfaat (Doa, 2001: 10).

Makna terminologi istilah yang digunakan dalam pembahasan fiqh Islamadalah "mengeluarkan sebagian dari harta tertentu yang telah mencapai nishab (takaran tertentu yang menjadi batas minimal harta tersebut diwajibkan untuk dikeluarkan zakatnya)", diberikan kepada mereka yang berhak menerimanya (berdasarkan pengelompokan yang terdapat dalam al Quran), dan harta tersebut merupakan milik sempurna dalam artian merupakan milik sendiri dan tidak terdapat kepemilikan orang lain di dalamnya serta telah genap usia pemilikannya selama setahun, hal ini dikenal dengan istilah haul (Qadir, 2001: 5). Undang-undang Nomor 38 tahun 1999 pasal 1 ayat 2 menyebutkan tentang definisi zakat:

"zakat adalah harta yang wajib disisihkan oleh seorang muslim atau badan yang dimiliki oleh orang muslim sesuai dengan ketentuan agama untuk diberikan kepada yang berhak menerimanya".

Yusuf Qardhawi membagi tiga tujuan zakat yaitu: dari pihak muzakki, pihak mustahik, dan masyarakat. Tujuan zakat dari pihak muzakki antara lain untuk menyucikan dari sifat bakhil, rakus, egois, dan sejenisnya (Qardhawi, 1988: 30). Serta menumbuhkan sifat pemurah, empati dan memiliki solidaritas kepada sesama. Sedangkan bagi mustahik adalah terpenuhinya kebutuhan hidup dan tersucikannya hati mereka dari rasa dengki dan kebencian yang sering menyelimuti hati mereka melihat orang kaya yang bakhil. Adapun tujuan zakat dari pihak masyarakat adalah zakat bernilai ekonomis, merealisasi fungsi 
harta sebagai alat perjuangan menegakkan agama Allah dan mewujudkan keadilan sosial ekonomi masyarakat pada umumnya.

Dalam menghitung potensi zakat telah ada beberapa ekonom muslim yang telah melakukannya. Menurut perhitungan Public Interest Research and Advocacy Center (PIRAC) tahun 2007 potensi zakat di Indonesia dengan melakukan survey kepada 2000 responden di 11 kota besar adalah sebesar Rp 9,09 triliun. Sedangkan menurut pakar ekonomi syariah Muhammad Syafii Antonio menyebut potensi zakat Indonesia dapat mencapai $\mathrm{Rp} 17$ triliun. Kemudian hasil riset terbaru dari Ivan Syaftian, peneliti dari Universitas Indonesia tahun 2008 potensi zakat profesi sebesar Rp 4,825 triliun per tahun. Serta adapula yang menghitung potensi zakat berdasarkan pendapatan domestik bruto suatu negara, penghitungan potensi zakat dilakukan dari 2,5\% dari pendapatan domestik bruto (PDB) negara. Akan tetapi perhitungan dengan menggunakan PDB masih dirasakan kurang tepat apabila dipergunakan bukan di negara Islam seperti Indonesia, karena PDB yang dihasilkan adalah campuran.

Namun jika dibandingkan dengan jumlah dana zakat yang dikumpulkan oleh Badan Amil Zakat Nasional (Baznas) serta digabung dengan seluruh lembaga amil zakat nasional pada tahun 2007, ternyata dana zakat yang dikumpulkan hanya mencapai sebesar Rp 600 miliar. Jika dibandingkan dengan potensi zakat minimal sebesar Rp 4,8 triliun, maka nilai Rp 600 miliar ini hanya 2,5\% dari potensi minimal yang ada. Hal ini memperlihatkan bahwa pengumpulan zakat masih sangat jauh dari potensi minimal yang dapat dikumpulkan.

Adapun yang menjadi sasaran dari dana zakat ini telah ditentukan oleh Allah swt dalam al Quran surat at Taubah ayat 60:

"Sesungguhnya harta zakat itu hanyalah untuk orang-orang fakir, orang-orang miskin, para amil zakat, orang-orang yang sedang dilembutkan hatinya (untuk Islam), budak (yang akan memerdekan dirinya), orang-orang yang berhutang, sabilillah, dan Ibnu Sabil. Semua itu merupakan kewajiban dari Allah, dan Allah Maha Mengetahui dan Maha Bijaksana." (QS At Taubah: 60)

Berdasarkan ayat di atas terdapat delapan kelompok (asnaf) kaum yang berhak untuk menerima zakat, yaitu kaum fakir, kaum miskin, amilin (pengelola zakat), mualaf (orang yang mendapatkan hidayah Islam), budak (hamba sahaya), gharimin (orang yang berhutang), untuk keperluan di jalan Allah (fi sabilillah), dan Ibnu Sabil (orang yang sedang bepergian untuk keperluan maslahat seperti menuntut ilmu dan bukan perjalanan maksiat).

Delapan golongan diatas dapat dibagi secara garis besar kepada dua tipe 
manusia. Tipe pertama, mereka yang mendapatkan jatah dari zakat karena membutuhkannya. Mereka mendapatkannya sesuai dengan keperluannya baik banyak maupun sedikit. Seperti fakir, miskin, untuk memerdekakan budak, dan Ibnu sabil. Tipe kedua, mereka yang mendapatkan bagian karena pertimbangan jasa dan manfaat, serta mereka yang berjuang di jalan Allah SWT. Bila seseorang tidak membutuhkan dan tidak ada pula manfaat pemberian zakat kepadanya, maka ia tidak berhak mendapatkan bagian zakat tersebut.

Dari delapan asnaf tersebut bisa kita perluas maknanya, sehingga dalam penyalurannya kita tidak hanya terpaku pada tekstual ayat semata.

Fakir merupakan suatu kondisi dimana seseorang tidak mempunyai sumber penghasilan sehingga hidupnya sehari-hari sangat kekurangan. Dalam pembahasan biasanya akan selalu dikaitkan dengan miskin, karena kemiripan situasi hidup yang dihadapinya.

Miskin merupakan kondisi dimana seseorang mempunyai sumber penghasilan akan tetapi penghasilan yang diperoleh masih sangat kecil sehingga tidak mampu untuk memenuhi kebutuhan hidupnya. Permasalahan yang muncul terkait dengan penentuan kemiskinan adalah bagaimana cara menetukan standar hidup minimal yang layak. Namun selain itu kemiskinan di sini dapat pula diartikan dengan kemiskinan intelektual atau kebodohan yang selama ini melekat pada kaum muslimin serta kemiskinan iman.

Amil, yaitu individu, lembaga atau institusi pengelola zakat. Mereka berhak menerima zakat karena untuk operasional dan biaya hidup mereka. Akan tetapi besaran jatah untuk amil dibatasi maksimal hanya 12,5\%. Diharapkan dengan memasukkan amil sebagai salah satu asnaf penerima zakat, akan memacu mereka untuk bekerja lebih baik lagi bagi kemaslahatan dan kesejahteraan umat.

Muallaf yaitu individu yang baru saja masuk ke dalam Islam. Mereka berhak menerima zakat, karena seringkali karena masuknya mereka ke dalam Islam membuat mereka dikucilkan dari kehidupan yang seringkali membuat mereka terkucil dalam hal ekonomi.

Riqab atau budak adalah kondisi dimana manusia diperlakukan tidak layak yang dianggap sebagai benda. Pada masa sekarang budak sudah tidak ada lagi akan tetapi kondisi yang mendekati hal tersebut masih ada, sebagai contoh adalah tenaga kerja Indonesia (TKI) terutama yang wanita seringkali menerima perlakuan yang tidak manusiawi dari majikannya. Karena di beberapa negara, pembantu masih dianggap sebagai budak.

Gharimin adalah individu yang terlilit hutang, dimana hutang tersebut 
dilakukan untuk memenuhi kebutuhan hidupnya dan bukan untuk keperluan maksiat seperti judi. Pada konteks kekinian timbul pemikiran apakah asnaf ini dapat diperluas dengan hutang yang dilakukan oleh negara, agar dana zakat mampu pula membebaskan pemerintah dari belitan hutang yang membelit.

Sabilillah merupakan kondisi individu yang berjuang untuk menegakkan agama Allah. Hal ini terjadi pada para mujahid Islam di Palestina atau Afganisthan yang berjuang untuk menegakkan agama Allah dalam melawan imperialisme Amerika Serikat dan sekutunya. Para mujahid ini berhak untuk menerima zakat yang ada. Dana bagi pembangunan masjid, rumah sakit, pesantren, madrasah maupun sekolah dapat dikategorikan sebagai perjuangan di jalan Allah (fi sabilillah), serta mampu memberikan kesegaran spiritual kepada kaum muslimin yang membutuhkan.

Ibnu Sabil yaitu individu yang sedang dalam perjalanan dimana perjalanan yang dilakukan adalah untuk kebajikan dan bukan untuk maksiat. Seseorang yang sedang dalam perjalanan dakwah berhak untuk mendapatkan zakat. Asnaf ini dapat pula diperluas menjadi beasiswa bagi para pelajar dan mahasiswa.

\section{Zakat dan Jaminan Sosial}

Penyelenggaraan sistem jaminan sosial telah menjadi agenda nasional di negara-negara berkembang yang didasari oleh kesadaran untuk mewujudkan keadilan sosial dan terpenuhinya agenda pembangunan sosial ekonomi. Kompetisi global memperkuat keyakinan negara berkembang untuk membentuk suatu sistem jaminan sosial yang kuat, terpadu dan terintegrasi.

Beberapa negara yang menganut welfare state yang selama ini memberikan jaminan sosial dalam bentuk bantuan sosial mulai menerapkan asuransi sosial. Utamanya karena jaminan melalui bantuan sosial membutuhkan dana yang besar dan tidak mendorong masyarakat merencanakan kesejahteraan bagi dirinya. Disamping itu, dana yang terhimpun dalam asuransi sosial dapat merupakan tabungan nasional. Secara keseluruhan adanya jaminan sosial nasional dapat menunjang pembangunan nasional yang berkelanjutan. Pengaturan dalam jaminan sosial ditinjau dari jenisnya terdiri dari jaminan kesehatan, jaminan kecelakaan kerja, jaminan pemutusan hubungan kerja, jaminan hari tua, pensiun, dan santunan kematian.

Dalam Undang-undang No. 40 tahun 2004 tentang Sistem Jaminan Sosial Nasional dapat didefinisikan bahwa:

"Jaminan sosial adalah perlindungan sosial untuk menjamin seluruh rakyat agar dapat memenuhi kebutuhan dasar hidupnya yang layak dan meningkatkan martabat hidupnya". 
Jaminan sosial mulai dikenal ketika Indonesia masih di bawah penjajahan Belanda. Saat itu Jaminan sosial berupa pensiun bagi para pegawai pemerintahan kolonial Belanda. Kemudian setelah negeri ini menyatakan proklamasinya, konsep jaminan sosial yang bertujuan menjamin kesejahteraan rakyat pada dasarnya tertuang dalam Dasar-Dasar Pokok daripada Plan Mengatur Ekonomi Indonesia atau landasan pemikiran bagi PPSE tertulis sebagai berikut: "Dasar politik perekonomian Indonesia ialah memenuhi keperluan hidup rakyat Indonesia menjadi rakyat yang makmur, jasmani dan rohani...".

Ditinjau dari definisinya, Jaminan Sosial dimaksudkan untuk menuju masyarakat yang sejahtera. Lantas cukupkah SJSN memenuhi tujuan tersebut, mengingat dalam sistem ini tetap saja masyarakat sebagai penyokong dana utama. Lantas di mana peran negara yang dalam konstitusi pasal 34 ayat (1) disebutkan "fakir miskin dan anak-anak terlantar dipelihara oleh negara". Serta ayat (2) yang meyebutkan "Negara mengembangkan sistem jaminan sosial bagi seluruh rakyat dan memberdayakan masyarakat yang lemah dan tidak mampu sesuai dengan martabat kemanusiaan”. Mencermati mekanisme UU No. 40 Tahun 2004 tentang SJSN, tampak bahwa pemerintah hanya sebagai regulator yang menerapkan subsidi silang dari masyarakat kaya ke masyarakat miskin.

Zakat merupakan ibadah yang berdimensi ganda, selain untuk menggapai keridhaan serta pahala dari Allah. Zakat merupakan ibadah yang berdimensi sosial. Dalam sejarah Islam, zakat banyak digunakan untuk kepentingan sosial. Wujud kepentingan sosial tersebut dapat berupa pemberdayaan masyarakat, jaminan sosial, pendidikan, kesehatan, dan lain-lain.

Zakat ini mempunyai dimensi sosial yang sangat mulia, yang menandakan bahwa ajaran Islam telah memikirkan mengenai solusi pemecahan permasalahan ketimpangan dan distrbusi pendapatan yang tidak merata di masyarakat jauh sebelum konsep pemerataan pembangunan dari negara-negara Barat muncul. Bahkan konsep zakat ini merupakan konsep jaminan sosial pertama yang terlebih dahulu muncul dibandingkan dengan konsep jaminan sosial yang saat ini diterapkan oleh negara-negara Barat. Meskipun sebenarnya strategi pembangunan negara-negara Barat banyak pula mengadopsi konsep Islam pada masa kejayaan. Telah banyak strategi pemerataan pembangunan yang telah dibuat oleh negara-negara barat, dan sampai saat ini belum ada satu pun yang membuktikan keberhasilan konsep-konsep tersebut secara merata terutama di negara-negara berkembang. Sebab konsep tersebut dikembangkan berdasarkan situasi dan kondisi yang terjadi di negara-negara Barat yang pada 
kenyataannya lebih maju dari negara-negara di belahan dunia lainnya.

Konsep pemerataan yang dianjurkan dalam Islam telah berhasil dibuktikan pada masa kekhalifahan Umar bin Abdul Aziz, dimana pada masa itu beliau pun mengalami kesulitan dalam pengelolaan zakat, namun kesulitan yang dihadapi beliau bukanlah kesulitan untuk mencari muzakki (orang yang mampu membayar zakat) melainkan kesulitan yang dihadapi adalah untuk mencari mustahik (orang yang membutuhkan), karena semua penduduk pada masa kekhalifahan Umar bin Abdul Aziz tidak ada yang mengalami kekurangan. Bahkan semua penduduknya tergolong pada penduduk yang wajib zakat. Ini membuktikan bahwa konsep yang dibawa oleh ajaran Islam telah mampu dibuktikan, meskipun pada situasi dan kondisi yang berbeda.

Beberapa bentuk pemberian zakat berdasarkan tipologi orang miskin dalam tiga golongan, yaitu (Qadir, 2001: 45):

Golongan yang tidak mempunyai kemampuan sama sekali untuk berusaha memenuhi kebutuhan hidupnya secara mandiri. Faktor yang menyebabkan mereka tidak mampu adalah seperti faktor usia yang telah lanjut (lansia) atau karena cacat jasmani permanen, yang menyebabkan mereka tidak mampu memenuhi kebutuhannya secara mandiri, maka cara pengentasannya adalah dengan memberikan jaminan hidup secara rutin dari dana zakat, bantuan zakat yang diberikan kepada golongan ini adalah zakat dalam bentuk bantuan konsumtif.

Mereka yang tergolong masih sehat fisik jasmani, tetapi tidak memiliki keterampilan apa pun, dimana inilah yang sebagian terdapat di masyarakat yaitu masyarakat miskin yang kurang berpendidikan dan kurang keahlian. Pengentasan kemiskinan untuk golongan ini adalah diberikan pelatihan dan pendidikan khusus, dan selanjutnya dipekerjakan pada unit-unit usaha ekonomi yang dikelola oleh amil zakat setempat sehingga mereka bisa mandiri dalam memenuhi kebutuhan hidupnya.

Mereka miskin karena suatu hal yang disebabkan terjadi musibah seperti bencana alam yang telah menghancurkan semua harta benda yang dimiliki, sedangkan fisik dan mentalnya masih potensial untuk bekerja dan berusaha, tetapi tidak memiliki modal, maka langkah pengentasannya adalah memberikan pinjaman modal usaha dari dana zakat.

Berdasarkan tipologi orang miskin yang dikategorikan oleh Abdurrachman Qadir tersebut, maka dapat disusun suatu sistem jaminan sosial dengan berbasis pada pendayagunaan zakat. Zakat dapat dipergunakan dalam berbagai bentuk sistem jaminan sosial, seperti asuransi tenaga kerja, asuransi 
pensiun dan asuransi jiwa. Serta untuk mengatasi berbagai macam masalah seperti perumahan, akses permodalan dan pendidikan bagi si miskin dapat dilakukan melalui memaksimalkan pengelolaan dan pendayagunaan zakat. Dengan pendayagunaan zakat sebagai suatu sistem jaminan sosial diharapkan program pengentasan kemiskinan dapat saling terintegratif dengan program pemerintah.

Namun agar zakat ini dapat optimal sebagai salah satu instrument dalam penerapan sistem jaminan sosial ialah diarahkan pada zakat yang bersifat produktif. Dana zakat yang terhimpun dikelola sepenuhnya untuk sesuatu yang produktif, sehingga dana zakat yang terhimpun dapat tumbuh dan berkembang. Selanjutnya dari hasil dana zakat tersebut dialokasikan sepenuhnya sebagai salah satu pendanaan dalam sistem jaminan sosial. Diharapkan dengan optimalisasi pengelolaan dana zakat ini, maka akan dapat terjadi sinkronisasi antara zakat dengan sistem jaminan sosial yang dikelola oleh pemerintah.

Apabila hal ini dapat diwujudkan, maka zakat akan dapat sinkron dengan UUD 1945 dalam pasal 34 ayat (2) dimana dinyatakan bahwa: "negara mengembangkan sistem jaminan sosial bagi seluruh rakyat dan memberdayakan masyarakat yang lemah dan tidak mampu sesuai dengan martabat kemanusiaan".

Karena sistem jaminan sosial akan mampu berdiri dengan dukungan berbagai sub sistem dalam perekonomian, dan tidak hanya diserahkan pada pemerintah semata.

Dalam pelaksanaannya, nanti bisa dipilah-pilah dalam bidang pemberdayaan apakah jaminan sosial yang dibiayai oleh hasil pengelolaan dari dana zakat. Hal ini bertujuan agar tidak saling tumpang tindih dengan jaminan sosial yang dikelola oleh pemerintah. Apabila seluruh sub-sistem dalam perekonomian dapat saling terintegratif, maka Indonesia akan mampu memiliki suatu sistem jaminan sosial yang lebih mapan dibandingkan dengan di negara-negara yang menganut welfare state yang sepenuhnya mengandalkan jaminan sosial hanya kepada pemerintah.

\section{Positioning Zakat dan Pajak dalam Perekonomian}

Selanjutnya akan dijelaskan bagaimanakah positioning zakat dan pajak dalam sistem ekonomi Islam. Hal ini penting untuk dijelaskan, karena berdasarkan kajian teori yang dilakukan memperlihatkan bahwa zakat sebenarnya lebih efektif dalam menggerakkan perekonomian terutama perekonomian di sektor riil dibandingkan dengan pajak. 
Terdapat beberapa perbedaan pendapat di antara para ekonom muslim mengenai posisi zakat dan pajak (Al Arif, 2010: 290):

Pandangan pertama yaitu bahwa zakatlah yang merupakan kewajiban bagi umat Islam dan sementara pajak hukumnya wajib hanya bagi non muslim (atau dalam bahasa instrumen fiskal dalam literatur Islam selama ini adalah jizyah). Sehingga dalam sistem pemerintahan Islam hanya zakat yang diperkenankan untuk dipungut untuk kaum muslim, sementara pajak hanya dikenakan kepada kaum non-muslim yang merupakan kompensasi atas perlindungan yang diberikan oleh pemerintahan Islam kepada mereka atau dengan kata lain jizyah merupakan pajak pribadi atas kaum non muslim.

Pandangan kedua yaitu bahwa zakat dan pajak sama-sama kewajiban negara sehingga keduanya wajib untuk dipenuhi oleh setiap warga negara dalam suatu pemerintahan. Pendapat ini dikemukakan pertama kali oleh Masdar F Mas'udi pada awal tahun 1990-an. Menurut beliau zakat dan pajak adalah suatu kewajiban, jika zakat merupakan aspek spiritual dari perintah Allah untuk menafkahkan harta secara baik dan benar, maka pajak merupakan upaya institusional perintah Allah tersebut.

Pandangan ketiga mengatakan bahwa zakat itu identik dengan pajak, atau zakat adalah bagian dari pajak pemerintah. Dengan asumsi berdasarkan dua hal yaitu kesatuan pemahaman dan kesatuan beban. Bila dihubungkan dengan kesatuan pemahaman bahwa zakat itu identik dengan pajak karena kesamaan unsur-unsurnya, istilahnya dan pengertiannya. Sementara bila dihubungkan dengan kesatuan beban, terdapat pendapat bahwa zakat itu menyerupai pajak dari segi beban harta yang harus dibayar oleh individu dan masyarakat yang mempunyai kedudukan yang sama di hadapan hukum, demikian juga pajak itu bagian terpenting beban harta untuk merealisasikan tujuan zakat itu sendiri. Dan keduanya baik pajak dan zakat merupakan salah satu instrumen fiskal utama.

Sementara pandangan keempat adalah memposisikan zakat sebagai suatu sumber penerimaan utama dalam sistem perekonomian suatu negara, sementara pajak hanya berfungsi sebagai penerimaan penunjang atau penerimaan tambahan. Sehingga zakat merupakan kewajiban yang harus ditunaikan oleh setiap warga negara, dan sementara penerimaan dari zakat belum memenuhi maka pemerintah boleh untuk memungut pajak. Akan tetapi apabila penerimaan dari zakat sudah memenuhi maka penerimaan dari pajak ditiadakan.

Berdasarkan UU No. 17 Tahun 2000 tentang Pajak Penghasilan pajak 
17 ayat (1) huruf a dan b, bahwasanya zakat bisa saja menurunkan pajak penghasilan secara ganda. Pertama, mengurangi penghasilan kena pajak. Kedua, untuk nilai tertentu juga menurunkan tarif progresif. Zakat sebagai pengurang pajak penghasilan dapat berpengaruh terhadap makroekonomi, antara lain (Al Arif, 2010: 291-292):

\section{Pengaruh terhadap Konsumsi Agregat}

Asumsi yang digunakan dalam pembahasan ini adalah: Pertama, zakat dikenakan atas semua harta perniagaan dan investasi yang mempunyai potensi untuk tumbuh yang dimiliki oleh kaum muslim. Kedua, pembayar zakat perniagaan cukup besar dan menguasai satu bagian tertentu dari pendapatan nasional. Ketiga, gerakan dakwah dan penyadaran zakat berhasil baik. Keempat, proporsi zakat yang dibayarkan tersebut tetap, sebesar tertentu dari pendapatan nasional. Kelima, zakat yang terkumpul dibagikan kembali kepada para mustahik. Keenam, mustahik yang menerima zakat mempunyai kecenderungan mengkonsumsi marjinal yang lebih tinggi secara signifikan dibanding muzakki. Ketujuh, di satu sisi zakat pendapatan dihitung sebagai komponen pengurang pajak penghasilan dan di sisi lain zakat yang diterima mustahik tidak wajib dikenai pajak.

Dengan zakat sebagai pengurang pajak penghasilan akan berpengaruh positif terhadap tingkat konsumsi agregat. Penerapan UU No. 17 Tahun 2000 ini akan meningkatkan kecenderungan mengkonsumsi rata-rata dan kecenderungan mengkonsumsi marjinal akan cenderung lebih besar apabila dibandingkan dengan kecenderungan mengkonsumsi rata-rata dan kecenderungan mengkonsumsi marjinal tanpa adanya zakat.

\section{Pengaruh terhadap Tabungan}

Tabungan adalah selisih langsung antara pendapatan nasional dengan konsumsi agregat. Zakat harta perniagaan akan berpengaruh negatif terhadap tabungan. Kecenderungan menabung rata-rata dan kecenderungan menabung marjinal dengan variabel zakat harta perniagaan lebih kecil dibandingkan kecenderungan menabung rata-rata dan kecenderungan menabung marjinal tanpa variabel zakat.

\section{Pengaruh terhadap Investasi}

Investasi adalah pengeluaran atau pembelanjaan para investor atau perusahaan untuk membeli barang modal dan perlengkapan produksi, dengan 
maksud menambah kemampuan memproduksi barang-barang dan jasa-jasa yang tersedia dalam perekonomian. Secara umum investasi biasa dibedakan menjadi investasi terpengaruh (induced investment) dan investasi otonom (autonomous investment).

Meskipun secara umum zakat sebagai pengurang penghasilan kena pajak telah memiliki pengaruh terhadap konsumsi agregat, tabungan dan investasi, dampaknya sebenarnya lebih kecil apabila zakat diposisikan sebagai komponen pengurang pajak penghasilan. Hal ini bisa digambarkan dengan ilustrasi sederhana dengan menggunakan perhitungan berdasarkan Undangundang No. 36 Tahun 2008 tentang pajak penghasilan.

Misalkan seseorang memiliki pendapatan bulanan Rp 5 juta/bulan atau setara dengan Rp 60 juta/tahun. Dan ia telah berkeluarga dengan 2 orang anak, maka penghasilan tidak kena pajaknya akan sebesar:

$R p 15.840 .000+R p 1.320 .000+R p 1.320 .000+R p 1.320 .000$ $=\mathrm{Rp} 19.800 .000,-$. Maka penghasilan kena pajaknya akan menjadi $\mathrm{Rp}$ 40.200.000,-.

Apabila individu tersebut telah membayar zakat sebesar Rp 1 juta, maka penghasilan kena pajaknya akan menjadi Rp 39.200.000,-. Sehingga pajak penghasilan yang harus dibayar adalah :

Rp 39.200.000 x 5\% = Rp 1.960.000,-. Maka total zakat dan pajak yang harus dibayarkan oleh individu tersebut adalah sebesar Rp 2.960.000,-.

Sekarang dengan kondisi yang sama namun saat ini zakat sebagai pengurang pajak penghasilan dan bukan pengurang penghasilan kena pajak. Besaran pajak yang harus dibayar adalah:

$\mathrm{Rp} 40.200 .000 \times 5 \%=\mathrm{Rp} 2.010 .000$. Apabila zakat yang telah dibayar adalah $\mathrm{Rp} 1$ juta rupiah, maka pajak yang harus dibayar adalah $\mathrm{Rp} 2.010 .000$ dikurangi dengan $\mathrm{Rp} 1$ juta rupiah menjadi Rp 1.010.000,-. Sehingga total pajak dan zakat yang harus dibayar adalah sebesar Rp 2.010.000,-.

Dengan dua ilustrasi di atas terlihat bahwa terdapat perbedaan yang cukup signifikan antara zakat sebagai pengurang penghasilan kena pajak dengan zakat sebagai pengurang pajak penghasilan. Tidak heran, banyak masyarakat yang memandang aturan saat ini dimana zakat sebagai pengurang penghasilan kena pajak justru menyebabkan beban pajak dan zakat yang harus mereka bayar lebih besar dibandingkan dengan hanya membayar pajak saja. Oleh karenanya pemerintah jika memiliki keinginan yang sungguh-sungguh untuk mengembangkan ekonomi syariah serta memiliki pengaruh yang cukup luas dalam perekonomian, maka zakat sebaiknya diletakkan sebagai 
pengurang pajak penghasilan. Apabila zakat diletakkan sebagai pengurang pajak penghasilan, maka ia akan memiliki pengaruh yang lebih besar kepada konsumsi agregat, tabungan, dan investasi dibandingkan dengan zakat hanya diposisikan sebagai pengurang penghasilan kena pajak.

\section{Simpulan}

Zakat merupakan salah satu instrument fiskal dalam perekonomian yang telah dipergunakan oleh pemerintahan Islam semenjak Rasulullah SAW, dan berdasarkan perjalanan sejarah zakat telah memainkan peran cukup penting dalam mekanisme distribusi pendapatan dalam perekonomian. Zakat merupakan aplikasi sistem jaminan sosial pertama kali di dunia sebelum banyak diterapkan di Negara barat. Zakat dapat dipergunakan dalam berbagai bentuk sistem jaminan sosial, seperti asuransi tenaga kerja, asuransi pensiun dan asuransi jiwa. Serta untuk mengatasi berbagai macam masalah seperti perumahan, akses permodalan dan pendidikan bagi si miskin dapat dilakukan melalui memaksimalkan pengelolaan dan pendayagunaan zakat. Hal ini dapat terwujud jika potensi zakat benar-benar dapat dieksplorasi secara efektif dan berdaya guna.

Zakat dan pajak merupakan dua instrumen fiskal yang dapat diterapkan oleh pemerintah sebagai upaya pendanaan pembangunan negara, terlepas dari khilafiyah pendapat ada yang diantara para ulama dan ekonom muslim. Zakat sebagai pengurang pajak penghasilan dapat berpengaruh terhadap makro ekonomi, antara lain berpengaruh terhadap tingkat konsumsi agregat dari masyarakat, tingkat tabungan, dan tingkat investasi. Selain itu zakat akan lebih optimal jika mampu sebagai pengurang pajak penghasilan dan bukan sekedar pengurang penghasilan kena pajak, berdasarkan simulasi perhitungan yang dilakukan memperlihatkan bahwa zakat sebagai pengurang pajak penghasilan mampu memberikan pengaruh yang lebih luas di dalam perekonomian dibandingkan dengan hanya sebagai pengurang penghasilan kena pajak.

\section{Daftar Pustaka}

Al Arif, M. Nur Rianto. 2010. Efek Pengganda Zakat Serta Implikasinya Terhadap Program Pengentasan Kemiskinan. Jurnal Ekbisi. Volume 5, No. 1, Desember 2010.

Doa, M Djamal. 2001. Membangun Ekonomi Umat: Melalui Pengelolaan Zakat Harta. Nuansa Madani: Jakarta. 
Kuncoro, Mudrajad. 1997. Ekonomi Pembangunan: Teori, Masalah, dan Kebijakan. UPP AMP YKPN: Yogyakarta.

Qadir, Abdurrachman. 2001. Zakat: Dalam Dimensi Mahdah dan Sosial. Srigunting: Jakarta.

Qardhawi, Yusuf. 1988. Hukum Zakat, alih bahasa Salman Harun, et.al. Pustaka Litera Antar Nusa dan Mizan: Jakarta. 